\title{
SUPPLEMENTATION WITH VITAMIN D - CURRENT RECOMMENDATIONS
}

\author{
Dimitar B. Marinov, Darina N. Hristova \\ Department of Hygiene and Epidemiology, Faculty of Public Health, Medical \\ University of Varna, Bulgaria.
}

\section{ABSTRACT}

Background: Vitamin D (calciferol) is a group of fatsoluble compounds, which are essential for calcium homeostasis, immunomodulation, antiproliferative effects, and more. It can also be viewed as a prohormone. Almost every cell in the human body has a receptor for vitamin D. Its synthesis depends on multiple factors.

Review results: Vitamin D deficiency affects almost $50 \%$ of the world's population, making it the most common vitamin deficit. There are multiple causes, mostly related to the modern lifestyle and ineffective exposition to the sun. The modern diet also lacks good sources of the vitamin, which makes supplementation the best option for optimal health. Supplements should be administered after serum level tests. Measurements below $20 \mathrm{ng} / \mathrm{ml}(50 \mathrm{nmol} /$ 1) are indication for supplementation. How effective the supplementation is will depend on the type of supplement, individual's genetic factors, and with what foods the supplement is taken with. Dietary reference values for adequate intake and tolerable upper limit should be taken into consideration as well. Serum levels above $30 \mathrm{ng} / \mathrm{ml}$ (above 70 $\mathrm{nmol} / \mathrm{l}$ ) are considered optimal for health. There is a risk of toxicity in cases of over-supplementation and serum levels above $150 \mathrm{ng} / \mathrm{ml}(375 \mathrm{nmol} / \mathrm{l})$.

Conclusion: The widespread vitamin D deficiency leads to many public health risks. Supplementation can have a therapeutic effect in many different conditions. To maximize the effect, and reduce the risks of toxicity, an individual assessment of the most appropriate regimen and the dosage of vitamin D supplementation is needed.

Keywords: vitamin D, supplementation, recommendations, safety, toxicity,

\section{BACKGROUND}

Vitamin D (calciferol) is a group of fat-soluble compounds, which are essential for the maintenance of the mineral balance inside the organism. The biological effects of vitamin D include the mediation of calcium homeostasis, immunomodulation, antiproliferative effects, and more [1].

Science has found out that almost every cell in the human body has a receptor for vitamin D (VDR) [2]. Given the pleiotropic effects of vitamin $\mathrm{D}$, it can be viewed as a prohormone.

In nature, vitamin D exists in two different forms. The first one is vitamin D2 (ergocalciferol), which is pro- duced by phytoplankton, yeast, and fungus under the effect of UV rays. Vertebrate animals, including humans, cannot produce vitamin D2, but the second one - vitamin D3 (cholecalciferol). It is synthesized in the stratum basale and stratum spinosum in the skin from 7-dehydrocholesterol when there is sufficient exposure to direct sunlight. Synthesis depends on the intensity of UV-B rays, atmospheric air pollution, season, geographic latitude and longitude, ozone layer thickness, cloudiness, time spent outside, clothing, sunscreen usage, skin color, and age [3]. Evidence suggests that skin aging reduces its capacity for vitamin D synthesis even during optimal sun exposure.

\section{REVIEW RESULTS}

Vitamin D deficiency affects almost $50 \%$ of the world's population [4]. This is the most common vitamin deficit. Scientists are calling it a pandemic [5]. It affects people of every age, gender, race, and region [6]. The causes for this are many but usually related to too short or ineffective exposition to the sun. Not spending enough time outside is a typical lifestyle for the modern person and contributes to the pandemic of vitamin D deficiencies.

Scientific evidence suggests that Vitamin D deficiency is related to many illnesses and pathological conditions [7]: liosis [8]

1. Rickets, osteoporosis, adolescent idiopathic sco-

2. Cardiovascular conditions - endothelial disfunction, vascular calcification, arterial hypertension, dyslipidemia [9]

3. Autoimmune diseases and infections [10, 11]

4. Metabolic diseases (obesity, type 2 diabetes) [12]. Patients with optimal vitamin D levels have better control over their body fat compared to deficient ones [13]

5. Neoplasia (breast, pancreas, colon, ovarian and testicular cancers) [1]

6. Neurological conditions (depression, dementia, schizophrenia, multiple sclerosis, Parkinson's) [14, 15]

7. Reproductive problems and pathological pregnancy $[16,17]$

There is also an association between vitamin D and physical performance [18]. Optimal levels boost speed and strength in athletes.

The modern diet often lacks popular nutritional sources of Vitamin D, such as oily fish and egg yolks [19]. The high incidence of human deficiency makes supplemen- 
tation the best option for improving health status.

The protective effect of vitamin D is manifested at blood levels above $30 \mathrm{ng} / \mathrm{ml}$ (above $70 \mathrm{nmol} / \mathrm{l}$ ). Lower levels and especially below $20 \mathrm{ng} / \mathrm{ml}(50 \mathrm{nmol} / \mathrm{l})$ is a deficiency indicator, and the use of therapeutic supplements are highly recommended [20].

The daily dosage of vitamin D supplements

The dosage regimen for vitamin $\mathrm{D}$ supplements depends on many factors: the severity of the deficiency, the type of vitamin supplement (D2 or D3), patient convenience, body weight (obese patients need higher doses than normal-weight patients due to extra fat), risk of overdose, etc. Also relevant is the genotype - in recent years, a number of polymorphism-related genes have been identified in VDR receptors and enzymes involved in the synthesis, hydroxylation, and transport of 25-hydroxyvitamin D (7-dehydrocholesterol reductase (DHCR7), polypeptide 1 (CYP2R1), etc.). Polymorphisms influence the response to a vitamin D supplement.
Ideally, supplements are administered after laboratory tests of serum vitamin D3 levels [21]. Measuring values below $20 \mathrm{ng} / \mathrm{ml}(50 \mathrm{nmol} / \mathrm{l})$, especially in the highrisk population groups, is an indication for vitamin D supplementation. It is recommended that vitamin D3 supplements should be used for significantly better bioavailability. Because vitamin D is a fat-soluble nutrient, it is important that the patients are properly instructed to take the supplement after meals or with fatty foods, preferably during the largest meal [22]. This ensures an optimal release of bile and pancreatic enzymes required for the absorption of vitamin D. Many medications and supplements reduce the absorption of vitamin D. Vitamin D supplements should not be taken during the same meal with statins, anticonvulsants, corticosteroids, and fiber-rich supplements.

When dosing with the supplement, it is important to take into account dietary reference values (DRVs) for Adequate Intake (AI) and Upper Tolerable Limit (UL) [23, 24].

Fig. 1. Dietary reference values (DRVs) for Adequate Intake (AI) and Upper Tolerable Limit (UL) for vit. D supplementation.

\begin{tabular}{|l|c|c|}
\hline \multicolumn{2}{|l|}{ Adequate Intake (AI) } & \multicolumn{3}{l|}{} \\
\hline Infants aged 7-12 months & $10 \mathrm{mkg}$ & $400 \mathrm{IU} / \mathrm{day}$ \\
\hline $\mathbf{1 - 7 5}$ years of age, pregnancy, and lactation & $15 \mathrm{mkg}$ & $600 \mathrm{IU} / \mathrm{day}$ \\
\hline Over the age of $\mathbf{7 5}$ & $20 \mathrm{mkg}$ & $800 \mathrm{IU} / \mathrm{day}$ \\
\hline Upper Tolerable Limit (UL) & & \\
\hline Infants aged 0-12 months & $25 \mathrm{mkg}$ & $1000 \mathrm{IU} / \mathrm{day}$ \\
\hline $\mathbf{1 - 1 0}$ years of age & $50 \mathrm{mkg}$ & $2000 \mathrm{IU} / \mathrm{day}$ \\
\hline Over the age of 10, pregnancy and lactation & $100 \mathrm{mkg}$ & $4000 \mathrm{IU} / \mathrm{day}$ \\
\hline
\end{tabular}

There are different regimens for taking supplements: daily dose or bolus (weekly or monthly). Choices are made individually, according to the severity of the deficit, the capabilities (including Intellectual) and the convenience of the individual. In bolus, the monthly dose can reach up to 50,000 IU. Evidence suggests that it may be more beneficial to take the supplement every day, thus providing a stable concentration of circulating vitamin D. Daily intake (rather than bolus) is advisable for endocrine and autoimmune diseases and for the prevention of respiratory infections.

Too high dosage supplementation, especially in the bolus regimen, carries the risk of toxic action. It is recommended to monitor the levels of vitamin D in blood with laboratory test: before supplementation and at every 6-month period. Levels of $25(\mathrm{OH}) \mathrm{D}$ in serum above 150 $\mathrm{ng} / \mathrm{ml}(375 \mathrm{nmol} / \mathrm{l})$ are potentially toxic [25]. There is an increased risk of toxicity in cases of:

- intake of more than 10,000 IU / day for 3 months or more

- intake of more than 300,000 IU per 24-hour period

\section{CONCLUSION:}

The widespread vitamin D deficiency leads to many public health risks. Supplementation can have a therapeutic effect in many different conditions. To maximize the effect, and reduce the risks of toxicity, an individual assessment of the most appropriate regimen and the dosage of vitamin D supplementation is needed. 
REFERENCES:

1. Holick MF. Vitamin D: a millenium perspective. J Cell Biochem. 2003 Feb 1;88(2):296-307. [PubMed] [Crossref]

2. Bikle DD. Vitamin D: an ancient hormone. Exp Dermatol. 2011 Jan;2 0(1):7-13. [PubMed] [Crossref]

3. Hoseinzadeh E, Taha P, Wei C, Godini H, Ashraf GM, Taghavi M, et al. The impact of air pollutants, UV exposure and geographic location on vitamin D deficiency. Food Chem Toxicol. 2018 Mar;113:241-254. [PubMed] [Crossref]

4. Nair R, Maseeh A. Vitamin D: The "sunshine" vitamin. J Pharmacol Pharmacother. 2012 Apr;3(2):118-26. [PubMed] [Crossref]

5. Cashman KD, Dowling KG, Skrabakova Z, Gonzalez-Gross M, Valtuena J, De Henauw S, et al. Vitamin D deficiency in Europe: pandemic? Am J Clin Nutr. 2016 Apr;103(4):1033-44. [PubMed] [Crossref]

6. Holick MF, Chen TC. Vitamin D deficiency: a worldwide problem with health consequences. Am J Clin Nutr. 2008 Apr;87(4):1080S-6S. [PubMed] [Crossref]

7. Caccamo D, Ricca S, Curro M, Ientile R. Health Risks of Hypovitaminosis D: A Review of New Molecular Insights. Int J Mol Sci. 2018 Mar 17;19(3):892. [PubMed] [Crossref]

8. Batista R, Martins DE, Hayashi LF, Lazaretti-Castro M, Puertas EB, Wajchenberg M. Association between vitamin $\mathrm{D}$ serum levels and adolescent idiopathic scoliosis. Scoliosis. 2014; 9(Suppl 1):O45. [PMC] [Crossref]

9. Alfieri DF, Lehmann MF, Oliveira SR, Flauzino T, Delongui F, de Araujo MCM, et al. Vitamin D deficiency is associated with acute ischemic stroke, Creactive protein, and short-term outcome. Metab Brain Dis. 2017 Apr; 32(2):493-502. [PubMed] [Crossref]

10. Kikuta J, Ishii M. [Current Top- ics on Vitamin D. The effects of vitamin $\mathrm{D}$ on the immune system] [in Japanese] Clin Calcium. 2015 Mar;25(3):359-65. [PubMed]

11. Szymczak I, Pawliczak R. The Active Metabolite of Vitamin D3 as a Potential Immunomodulator. Scand $J$ Immunol. 2016 Feb;83(2):83-91. [PubMed] [Crossref]

12. Rafiq S, Jeppesen PB. Body Mass Index, Vitamin D, and Type 2 Diabetes: A Systematic Review and MetaAnalysis. Nutrients. 2018 Aug 28; 10(9):1182. [PubMed] [Crossref]

13. Mason C, Xiao L, Imayama I, Duggan C, Wang C-Y, Korde L, et al. Vitamin D3 supplementation during weight loss: a double-blind randomized controlled trial. Am J Clin Nutr. 2014 May;99(5):1015-25. [PubMed] [Crossref]

14. Munger KL, Hongell K, Aivo J, Soilu-Hanninen M, Surcel H-M, Ascherio A. 25-Hydroxyvitamin D deficiency and risk of MS among women in the Finnish Maternity Cohort. Neurology. 2017 Oct 10;89(15):1578-1583. [PubMed] [Crossref]

15. Gatto NM, Paul KC, Sinsheimer JS, Bronstein JM, Bordelon Y, Rausch $\mathrm{R}$, et al. Vitamin $\mathrm{D}$ receptor gene polymorphisms and cognitive decline in Parkinson's disease. J Neurol Sci. 2016 Nov 15;370:100-106. [PubMed] [Crossref]

16. Dennis NA, Houghton LA, Pankhurst MW, Harper MJ, McLennan IS. Acute Supplementation with High Dose Vitamin D3 Increases Serum AntiMullerian Hormone in Young Women. Nutrients. 2017 Jul 8;9(7):719. [PubMed] [Crossref]

17. Tamblyn JA, Hewison M, Wagner CL, Bulmer JN, Kilby MD. Immunological role of vitamin $\mathrm{D}$ at the maternal-fetal interface. $J$ Endocrinol. 2015 Mar;224(3):R107-21. [PubMed]

\section{[Crossref]}

18. Alimoradi K, Nikooyeh B, Ravasi AA, Zahedirad M, Shariatzadeh N, Kalayi A, et al. Efficacy of Vitamin D Supplementation in Physical Performance of Iranian Elite Athletes. Int J Prev Med. 2019 Jun 7;10:100. [PubMed] [Crossref]

19. Lehmann U, Gjessing HR, Hirche F, Mueller-Belecke A, Gudbrandsen OA, Ueland PM, et al. Efficacy of fish intake on vitamin D status: a meta-analysis of randomized controlled trials. Am J ClinNutr. 2015 Oct;102(4): 837-47. [PubMed] [Crossref]

20. Holick MF, Binkley NC, Bischoff-Ferrari HA, Gordon CM, Hanley DA, Heaney RP, et al. Evaluation, treatment, and prevention of vitamin D deficiency: an Endocrine Society clinical practice guideline. J Clin Endocrinol Metab. 2011 Jul;96(7): 1911-30. [PubMed] [Crossref]

21. Stokes CS, Lammert F. Vitamin D supplementation: less controversy, more guidance needed. F1000Res. 2016 Aug 17;5:F1000 Faculty Rev2017. [PubMed] [Crossref]

22. Mulligan GB, Licata A. Taking vitamin D with the largest meal improves absorption and results in higher serum levels of 25-hydroxyvitamin D. $J$ Bone Miner Res. 2010 Apr;25(4):92830. [PubMed] [Crossref]

23. Vitamin D: EFSA sets dietary reference values. EFSA. 28 October 2016. [nternet]

24. [Legislation No.1 by Ministry of Health from 22nd Jan. 2018 about the physiological norms of nutrition of the population of Bulgaria] Ministry of Healthcare. 2018. [in Bulgarian]

25. Vieth R. Vitamin D supplementation, 25-hydroxyvitamin D concentrations, and safety. Am J Clin Nutr. 1999 May;69(5):842-56. [PubMed]

Please cite this article as: Marinov DB, Hristova DN. Supplementation with vitamin D - current recommendations. $J$ of IMAB. 2021 Jan-Mar;27(1):3554-3556. DOI: https://doi.org/10.5272/jimab.2021271.3554

\author{
Address for correspondence \\ Dimitar Borisov Marinov, \\ Medical University - Varna; 55 Marin Drinov Str., Varna, Bulgaria \\ E-mail: mitak_1992@abv.bg
}

